\title{
Elements of nonsense in the modern English fairy-tale (based on "The BFG, the Big Friendly Giant" by Roald Dahl)
}

\author{
E. Y. Koltysheva ${ }^{1}$, E. V. Novik ${ }^{1}$
}

${ }_{1}^{1}$ P. G. Demidov Yaroslavl State University, 14 Sovetskaya str., Yaroslavl 150003, Russian Federation

DOI: $10.18255 / 2412-6519-2020-4-380-387$

Research Article Full text in Russian

In the paper the definition of the fairy-tale is given and the features of the English fairy-tale are discussed. Being a game in the first place nonsense is considered to be the hallmark of the English fairy-tale. Nonsense may be considered both as a genre and as a literary device. The study is based on "The BFG", an example of the English fairy-tale, written by the famous English writer Roald Dahl, who is known for using nonsense a lot in his works. The results of the literary and linguistic (on phonological, morphological, lexical, syntactic, semantic and graphic levels) analysis of "The BFG" are presented in the article. The authors come to the conclusion that the fairy-tale by Roald Dahl cannot be considered an example of "pure nonsense" despite some features of the genre. It is found out that nonsense as a literary device in the fairy-tale is based on the principles of the language game on all language levels. The fact that the book is written for children is reflected in the language of "The BFG". The main character's speech reminds of children's speech which is characterised by the language game.

Keywords: literary fairy-tale; English literary fairy-tale; Roald Dahl; "The BFG, the Big Friendly Giant"; nonsense; genre; literary device; language game

INFORMATION ABOUT THE AUTHORS

$$
\begin{array}{r|l}
\text { Koltysheva, Elena Yu. } & \begin{array}{l}
\text { E-mail: ekoltyshev@mail.ru } \\
\text { Cand. Sc. (Philology), Associate Professor }
\end{array} \\
\text { Novik, Evgenia V. } & \text { E-mail: eugenianov@yandex.ru }
\end{array}
$$

For citation: Koltysheva E. Y., Novik E. V. Elements of nonsense in the modern English fairy-tale (based on "The BFG, the Big Friendly Giant" by Roald Dahl) // Social'nye i gumanitarnye znanija. 2020. Vol. 6, No 4. P. 380387. (in Russ.) 


\title{
Элементы нонсенса в современной английской литературной сказке (на примере сказки Роальда Даля «БДВ, или Большой и Добрый Великан»)
}

\author{
Е. Ю. Колтышева ${ }^{1}$, Е. В. Новик ${ }^{1}$
}

1Ярославский государственный университет им. П.Г. Демидова, ул. Советская, 14, Ярославль, 150003, Российская Федерация

DOI: $10.18255 / 2412-6519-2020-4-380-387$

УДК $821.111: 81 ` 38$

Научная статья

Полный текст на русском языке

В статье даётся определение литературной сказки, приводятся особенности английской литературной сказки, рассматривается понятие нонсенса. Нонсенс, представляющий собой прежде всего игру, считается чертой, отличающей английскую литературную сказку. Нонсенс может рассматриваться как жанр и как языковой приём. В качестве примера для анализа используется популярное произведение «БДВ, или Большой и Добрый Великан», являющееся примером современной литературной сказки, известного английского писателя-сказочника Роальда Даля, в творчестве которого часто встречается нонсенс. В статье приводятся результаты комплексного литературоведческого и лингвистического, проведённого на фонологическом, морфологическом, лексическом, синтаксическом, семантическом и графическом уровнях языка, анализа текста сказки «БДВ, или Большой и Добрый Великан». Авторы статьи приходят к выводу, что рассматриваемое произведение Р. Даля не является примером «чистого нонсенса», в сказке присутствуют только некоторые черты этого жанра. В ходе анализа определяется, что как приём нонсенс в произведении строится на приёмах языковой игры на всех уровнях языка. Язык сказки - речь главного героя напоминает детскую речь, для которой характерна языковая игра - свидетельствует о направленности произведения Роальда Даля на детскую аудиторию.

Ключевые слова: литературная сказка; английская литературная сказка; Роальд Даль; «БДВ, или Большой и Добрый Великан»; нонсенс; жанр; языковой приём; языковая игра

ИНФОРМАЦИЯ ОБ АВТОРАХ

\begin{tabular}{r|l} 
Колтышева, Елена Юрьевна & $\begin{array}{l}\text { E-mail: ekoltyshev@mail.ru } \\
\text { Кандидат филологических наук, доцент }\end{array}$ \\
Новик, Евгения Владимировна & Email: eugenianov@yandex.ru
\end{tabular}

Для цитирования: Колтышева Е. Ю., Новик Е. В. Элементы нонсенса в современной английской литературной сказке (на примере сказки Роальда Даля «БДВ, или Большой и Добрый Великан») // Социальные и гуманитарные знания. 2020. Том 6, № 4. С. 380-387.

(C) Колтышева Е. Ю., Новик Е. В., 2020

Статья открытого доступа под лицензией СС BY (https://creativecommons.org/licenses/by/4.0/) 
Для многих путешествие в мир литературы начинается со сказки. Этот жанр имеет долгую историю; с течением времени он изменялся, приобретал новые черты. Так, со временем появилась литературная сказка. Писатели и по сей день обращаются к этому жанру, поскольку сказка не ограничивает, в ней есть простор для воображения. В сказке можно всё перевернуть с ног на голову, другими словами, в ней может царить нонсенс, элементы которого содержат в себе и сказки британского писателясказочника, любимого автора как детей, так и взрослых, Роальда Даля. Особенно яркое использование нонсенса наблюдается в его сказке про большого и доброго великана «БДВ».

Нонсенс - уникальная черта, присущая английской сказке. Многие учёные проявляют большой интерес к изучению английской литературной сказки и нонсенса. Их работы посвящены:

- истории и особенностям жанра английской литературной сказки (М. А. Аксюченко, А. П. Лаврентьева, Н. Н. Мамаева);

- лингвостилистическому анализу текстов современной английской сказки (А. О. Тананыхина);

- анализу нонсенса как литературного жанра (С. З. Иткулов, Н. С. Лейтес, Н. В. Соболева);

- специфике нонсенса в детской литературе (Н. М. Демурова, И. Н. Ширяева);

- яыковой игре, которую представляет собой нонсенс как литературный приём (О. Ю. Коновалова, И. Н. Ширяева).

Анализ элементов нонсенса в сказке «БДВ» позволяет определить, насколько нонсенс присущ данному произведению.

Новизна исследования заключается в комплексном анализе элементов нонсенса в пользующейся на сегодняшний день большой популярностью современной сказке Роальда Даля «БДВ».

Основной целью работы является анализ выбранного произведения и выявление в нём элементов нонсенса как жанра и как приёма.

В ходе исследования были использованы методы системно-структурного подхода, литературоведческого анализа текста, структурно-лингвистического анализа, позволяющие выявить элементы нонсенса в сказке Роальда Даля «БДВ».

Согласно Л. Ю. Брауде, литературной сказкой является «авторское художественное прозаическое или поэтическое произведение, основанное либо на фольклорных источниках, либо сугубо оригинальное; произведение преимущественно фантастическое, волшебное, рисующее чудесные приключения сказочных героев и в некоторых случаях ориентированное на детей; произведение, в котором волшебство, чудо играет роль сюжетообразующего фактора, служит основной отправной точкой характеристики персонажей» [1, с. 234].

Литературные сказки каждого народа имеют, в свою очередь, собственные особенности. Вслед за А. П. Лаврентьевой, М. А. Аксюченко и Н. Н. Мамаевой можно выделить следующие черты, присущие английской литературной сказке:

- единство стиля;

- в основе лежат миф и эпос;

- главный герой произведения - ребёнок;

- противопоставление двух миров: детского и взрослого;

- наличие героя, совмещающего черты ребёнка и взрослого, помогающего главному герою исследовать «взрослый мир»;

- обращение как к детям, так и взрослым, многослойность произведения; 
- чувство слова, владение языком и его всевозможные трансформации [2, с. 196-199];

- обращение к уже созданным ранее сказочным мирам [3, с. 97].

Ещё одной уникальной, по мнению большинства исследователей, присущей исключительно английской литературе, в том числе и сказке, чертой является нонсенс. Его появлением английская литература обязана Льюису Кэрроллу и Эдварду Лиру. Нонсенс можно рассматривать с двух позиций: как жанр и как приём [4].

И. Н. Ширяева выделяет следующие общие черты литературного нонсенса как жанра:

• сочетание хаоса и порядка; того, что невозможно в одной ситуации и контексте;

- организующее начало, позволяющее структурировать смысловое наполнение текста (деление на главы, визуальное деление (отступы в тексте), отдельные образы и мотивы. Очень часто организующее начало - игра, которая помогает авторам поместить абсурд, с первого взгляда бессмыслицу, в реальные, традиционные условия, знакомые читателю);

- баланс между значением и его отсутствием (когда за одним смысловым нарушением открываются или создаются новые смыслы; привычный ход мыслей нарушается, но создаётся новая философия, пусть и противоречащая здравому смыслу, но обладающая собственной логикой и стройностью);

- отсутствие чувства опасности (поскольку всё есть игра и, соответственно, нечего бояться);

- богатая стилистика, обилие приёмов языковой игры;

- две модели - норма и её оппозиция, то есть двоемирие;

- интертекстуальность [5, с. 57-60].

Один из авторов, в творчестве которого часто встречается нонсенс как жанр и как прием, - Роальд Даль - английский писатель норвежского происхождения, любимый сказочник и детей, и взрослых.

Безусловно, Роальд Даль оказал огромное влияние на детскую литературу. Но что же делает английского сказочника одним из самых популярных среди детей авторов? Писатель сам раскрывает составляющие, необходимые хорошему писателю для детей:

«He must like simple tricks and jokes and riddles and other childish things. He must be unconventional and inventive. He must have a really first-class plot. He must know what enthralls children ad what bores them... They love suspense. They love action... They love chocolates and toys and money... They love being made to giggle. They love seeing the villain meet a grisly death. They love a hero and they love the hero to be a winner. But they hate descriptive passages and flowery prose... Many of them are sensitive to good writing and can spot a clumsy sentence» [6, c. 2].

То есть для того, чтобы быть «правильным» детским автором, писателю самому нужно быть ребёнком, думать, как ребёнок, быть с детьми на одной волне.

Произведения Р. Даля для детей - это особые миры, в которых писатель разговаривает с детьми на понятном им языке (с использованием каламбуров, окказионализмов, различных нарушений правил и т. д.), в которых есть место для игры, для бессмыслицы, для нонсенса. В то же время в его произведениях нашли отражение многие события из его нелёгкой жизни.

Писатели критикуют за его не всегда лестное изображение отношений в семье, правосудия, мести и многого другого. Мир взрослых очень часто представляется 
в произведениях Роальда Даля жестоким, в нём царит несправедливость, от которой дети пытаются сбежать. Именно поэтому многие взрослые ставят под вопрос пригодность книг Даля для детей.

Однако произведения Даля должны рассматриваться как поучительные истории, где, конечно, есть место и жестокости, но при этом читающий должен знать, что эта история - лишь фантазия, выдумка, которая должна восприниматься с определённой «отчуждённостью», что детям, как никому другому, удаётся лучше всех.

Особый язык, безусловно, является отличительной чертой Роальда Даля. Писатель учит детей не только любить читать, но и наслаждаться языком и не бояться играть с ним. Как говорит БДВ в одноимённой сказке, автор постоянно 'gobblefunks' с языком [7, с. 78].

Дэвид Радд делит характерные черты стиля автора на 5 групп:

- фонологические (аллитерация, ассонанс);

- лексические (окказионализмы, изменение идиом, спунеризмы);

- синтаксические (спряжение глаголов (только в «БДВ»));

- семантические (игра слов, сравнение, adnominatio);

- графические (комбинирование заглавных и строчных букв, разные шрифты, курсив, жирный шрифт, нарушение целостности текста).

Кроме того, Радд отмечает, что 'narrative voice', то есть голос автора, читатель слышит почти во всех произведениях сказочника - речь многих героев из разных книг похожа - в этом и прослеживается автор. Иногда Роальд Даль сам появляется в произведении в роли повествователя. Он может дать совет читателям, спросить его мнение или же попросить его посмотреть на картинку, что создаёт эффект того, что всё происходит здесь и сейчас.

Также для Роальда Даля характерно использование гиперболы, ономатопеических слов, восклицаний, повторов [8, с. 56-60].

Одним из самых известных на сегодняшний день произведений английского сказочника Роальда Даля является «БДВ, или Большой и Добрый Великан». Это чудесная сказка о двух одиноких созданиях из разных миров, нашедших друг друга и ставших самыми близкими друзьями. Софи - сирота, родители которой умерли, когда она была совсем маленькой, и БДВ - одинокий великан-вегетарианец, у которого совсем нет друзей в его мире.

Литературный анализ произведения Роальда Дала показал, что эта сказка соответствует всем вышеперечисленным критериям английской литературной сказки:

- сказка написана в едином стиле;

- в основе лежит английская сказка 'Jack and the Beanstalk', «Джек и бобовый стебель»: герои сказки - великаны; в «БДВ» есть аллюзия на эту сказку (в кошмаре, приснившемся самому свирепому из великанов, ему явился тот самый Джек - покоритель великанов);

- главный герой произведения - ребёнок, девочка-сирота Софи;

- в сказке противопоставляется мир детей и взрослых, среди взрослых также существует деление на «хороших» взрослых - королева Великобритании - и «плохих» взрослых - миссис Клонкерс - владелица приюта, где жила Софи; такое же деление существует и в мире великанов: БДВ - добрый великан, все остальные - злые и жестокие;

- наличие героя, совмещающего черты взрослого и ребёнка, помогающего главному герою, - БДВ, открывающий тайны существования Софи;

- обращение и к детям, и ко взрослым; 
- владение языком, его трансформации - обилие приёмов языковой игры, которые будут рассмотрены ниже;

- обращение к уже созданным ранее сказочным мирам - сказочный мир великанов.

В ходе настоящего исследования было выявлено, что сказка «БДВ» не является примером чистого литературного нонсенса. Ей присущи лишь некоторые черты нонсенса как литературного жанра, и они имеют свои особенности:

1. Визуальное деление - разделение книги на главы. Всего в сказке 24 главы, они не пронумерованы, но каждая имеет название. Например, «Journey to Dream Country», «The Palace», «Capture» и так далее.

2. В конце произведения мы узнаём о том, что автором всей книги является сам Большой и Добрый Великан, которого Софи научила читать и грамотно писать, то есть организующим началом в произведении является БДВ.

3. Сочетание реального и нереального в сказке выражается следующим образом: в жизни обычной английской девочки-сироты Софи внезапно, в «ведьмин час», появляется БДВ, который похищает и уносит её в свою страну. В самом начале Софи, конечно, была напугана и не могла поверить в произошедшее с ней, однако очень скоро она воспринимала мир великанов как само собой разумеющееся. То есть само существование великанов в книге естественно вписывается в реальный мир, в котором живут самые обычные люди. Нонсенс заключается ещё и в том, что великанылюдоеды каждую ночь съедают людей (которые, в свою очередь, разные на вкус) из разных стран и этого никто не замечает до тех пор, пока Софи, придумав хитроумный план, не обращается за помощью к королеве [9].

4. Отсутствие смысла и его одновременное наличие, например, выражается в том, что «люди из Панамы имеют очень сильный шляпный вкус» («Human beans from Panama is tasting very strong of hats» [9, с. 19]) - здесь одновременно смысл отсутствует (как люди могут быть шляпного вкуса? Почему люди разные на вкус?), но в то же время он присутствует (панама - шляпа, следовательно, панамцы обладают шляпным вкусом).

5. Кроме того, сон также является важной составляющей сказки. Чтобы Королева поверила в существование великанов, Большой и Добрый Великан - ловец снов - и Софи приготовили нужный для неё сон. Идея о том, что можно ловить и смешивать сны, существование возможности приготовить абсолютно любой сон, в котором может произойти всё, что угодно (например, в одном из них мальчик написал книгу, которой зачитывались все: прохожие и водители за рулём так, что на дорогах было много аварий, стоматологи и пациенты во время приёма, футболисты на поле, спортсмены на Олимпиаде во время забега - всем было безразлично, что происходило вокруг, все были увлечены книгой) являют собой нонсенс [9, с. 100-101].

Так как нонсенс - это прежде всего игра, то и на уровне языка нонсенс также представляет собой игру, языковую игру - определённую необычность, неправильность, сознательно допускаемую автором. Нонсенс как языковой приём реализуется на фонологическом, морфологическом, лексическом, синтаксическом, семантическом и графическом уровнях языка.

В ходе анализа сказки «БДВ» нами были выявлены и проанализированы приёмы на всех вышеперечисленных уровнях языка:

1. На фонологическом уровне языка Роальд Даль чаще всего использует такой приём, как аллитерация (18 случаев использования), «Mucky little midget!», «Squaggy little squib!». «Именно этот приём привлекает внимание читателя к предложению, 
позволяет ему более эмоционально (в зависимости от цели высказывания) и ритмично звучать [9, с. 67];

2. На морфологическом уровне наиболее часто писатель нарушает правила образования форм множественного числа (5 случаев использования): «From now on, we is keeping as still as winky little micies» [9, с. 73] (вместо правильной формы 'little mice'), т. к. такие же ошибки совершают дети, когда учатся говорить, а сказка написана в первую очередь для детей.

3. Языковая игра Роальда Даля на лексическом уровне характеризуется:

- обилием окказионализмов (303 окказионализма и 10 окказиональных антропонимов), 'clumpety-clumpety-clump' (фонетический окказионализм); 'thingalingaling' (лексический окказионализм 'thing' - 'an object that one need not, cannot, or does not wish to give a specific name to', '-ling' - суффикс); 'snozzcumber' (лексический и фонетический окказионализм, 'snozz' - не зафиксировано в словаре, 'cumber' - часть слова 'cucumber', фонетический и лексический, 'snozzcumber' - единственный овощ, растущий в стране Великанов, и вегетарианцу БДВ приходится питаться только им);

- изменением идиом, устойчивых выражений и пословиц (43 случая использования) 'all in one lump' ('all in one piece' - «благополучно, без ущерба» - замена одной из частей выражения другой, при этом сохраняется смысл выражения, 'lump'- «кусок»); 'make teeth stand on end' ('make one's hair stand on end' - «волосы встали дыбом» - замена одного из элементов идиомы другим с искажением смысла, трудно представить зубы, вставшие дыбом, поэтому, не зная исходной идиомы, догадаться о значении оказывается не так просто); 'absolutely out of the window' ('absolutely out of the question' - «об этом не может быть и речи» - замена одного из элементов идиомы, 'window' - «окно», 'question' - «вопрос», но о значении выражения можно догадаться - «что-то, что не вписывается в определённые рамки»] [9].

Эти приёмы также показывают направленность сказки на детей, поскольку именно им свойственен процесс словотворчества и других преобразований языковых единиц.

4. На синтаксическом уровне английский сказочник нарушает ряд правил с целью позабавить читателя и создать иллюзию детской речи, ощущение абсолютного хаоса, характерного для нонсенса. Чаще всего Роальд Даль нарушает правила спряже-

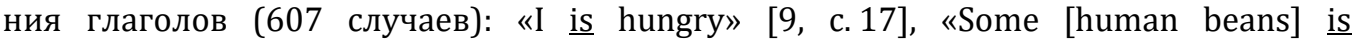
scrumdiddlyumptious and some is uckyslush» [9, c. 18]. А также писатель использует глаголы чувственного восприятия, умственного процесса, эмоционального состояния в Present Continuous (120 случаев): «... human beans is not really believing in giants, is they?» [9, c. 23], «Secrets that nobody is ever hearing before» [9, c. 32].

5. На семантическом уровне автор использует множество приёмов, которые не позволяют читателю скучать, постоянно заставляют его думать и быть внимательным во время чтения. Наиболее частыми приёмами на семантическом уровне, встречающимся в «БДВ», являются игра слов, а именно каламбур (21 случай): «Turks from Turkey is tasting of Turkey» [9, с. 18] - «турки на вкус, как индейка», игра слов основана на омонимии 'Turkey' - название страны - и 'turkey' - вид птицы;

«Human beans from Jersey is tasting of cardigans» $[9$, с. 20] - «люди с острова Джерси имеют шерстяной вкус», в этом случае игра слов основана на омонимии 'Jersey' - Джерси, название острова в проливе Ла-Манш, в составе Островной Нормандии - и 'jersey' - джерси, трикотажное полотно из шерстяных, хлопчатобумажных и других нитей; и сравнение (6 случаев): 'dotty as a dogswoggler' [9, c. 50], 'quacky as a duckhound' $[9$, c. 58]. 
6. Даже на графическом уровне Роальд Даль использует множество различных приёмов, позволяющих привлечь внимание читателя: аббревиация ('the BFG'), тюрлюпинада ('уou is a norphan', 'a sistanse'), использование разных шрифтов (7 случаев), а также выделение важных слов курсивом (58 случаев) [9].

Таким образом, основываясь на результатах исследования, можно сделать следующие выводы:

- Сказку Роальда Даля «БДВ» нельзя отнести к произведениям «чистого нонсенса», в ней есть лишь некоторые черты этого жанра (визуальное деление, наличие организующего начала, сочетание реального и нереального, одновременное отсутствие и наличие смысла, богатство языковых и стилистических приёмов), которых, однако, оказывается недостаточно для того, чтобы признать нонсенс жанром этой сказки.

- В «БДВ» нонсенс как приём строится на языковой игре на всех существующих уровнях языка: фонологическом, морфологическом, лексическом, синтаксическом, семантическом и графическом.

- Помимо того, что «БДВ» - сказка, направленность на детскую аудиторию показывает язык, с которым без ограничений играет Роальд Даль. Главный герой сказки, БДВ, странно разговаривает, поскольку именно так разговаривают дети, к которым и обращается автор, именно язык, помимо сюжета, привлекает внимание детей.

Проведённое исследование предполагает дальнейшее изучение и анализ нонсенса как жанра и как приёма в произведениях Роальда Даля, а также в произведениях других английских авторов.

\section{Ссылки / References}

1. Брауде Л. Ю. К истории понятия «Литературная сказка» // Известия АН СССР. Серия литературы и языка. 1977. Т. 36. № 3. С. 234.

2. Лаврентьева А. П., Аксюченко М. А. Становление английской литературной сказки // Молодой ученый. 2015. № 22.1. С. 196-199.

3. Мамаева Н. Н. «Светлее алмазов горят в небе звезды»: (Английская литературная сказка как явление) // Известия Уральского государственного университета. 2000. № 15. C. 96-106.

4. Чарская-Бойко В. Ю. Нонсенс - искусство викторианской Англии, 2011. URL: http://19veuro-lit.niv.ru/19v-euro-lit/articles-eng/charskaya-bojko-nonsens.htm (дата обращения: 03.03.2020).

5. Ширяева И. Н. Специфика литературной нонсенс-сказки // Филологические науки. Вопросы теории и практики. Тамбов: Грамота, 2017. Вып. 8 (74): в 2-х ч. Ч. 2. С. 56-60.

6. Dahl R. Writing children's books: An author of classics reflects on what it takes to succeed in this genre: giving young, readers what they want. Writer (Kalmbach Publishing Co.). Sep. 2009. Vol. 122. Issue 9. P. 2.

7. Srničková V. Translating Nonsense in Roald Dahl’s Children's Books. 2014. 105 p.

8. Rudd D. Don't gobbelfunk around with words: Roald Dahl and Language. Macmillan, 2012. $224 \mathrm{p}$.

9. Dahl R. The BFG / Illustrations - Q. Blake. L.: Puffin Books, 2016. 214 p. 